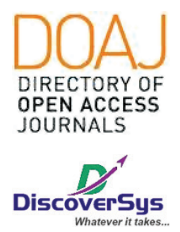

Published by DiscoverSys

\title{
Analisis hubungan Rasio Trombosit Limfosit (RTL) dengan derajat keparahan stenosis pada pasien Coronary Artery Disease (CAD)
}

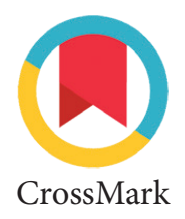

\author{
Zahra Inayah Kasim, ${ }^{1 *}$ Sulina Yanti Wibawa, ${ }^{2}$ Darmawaty E. Rauf ${ }^{3}$
}

\section{ABSTRACT}

Background: Atherosclerosis in CAD is marked by formation of plaque inside the arterial lumen. Platelet plays a role on formation and development of atherosclerosis. Adhesion of platelets to the endothelial cells followed by releasing platelet granules caused inflammation of endothel. Lymphocytes also play a role in atherosclerosis and atherotrombosis. T lymphocyte was the first to be recruited inside atheromas and gathered along inside an unstable plaque. The severity of stenosis can be calculated using Gensini score. The Aim of this study is to analyze the correlation between PLR and degree of stenosis in CAD.

Methods: This study is a retrospective study by collected 110 patients with $C A D$ that had undergone coronary Angiography. Platelets and lymphocyte count were measured by automatic haematologycal analyzer. PLR was measured by dividing trombocyte count with absolute lymphocyte. Angiography findings were calculated using Gensini score and later devided into 3 groups according to degree of severity.

Results: 110 patients retrospectively assesed, $80 \%$ were male and $20 \%$ female. The most age found was $50-59$ years (35.5\%). Using Anova test there is a significant differences on PLR between 3 groups of lesions $(p<0.05)$. Continued with Posthoc test, the only significant finding was PLR between moderate and severe lesion. By Spearman's Correlation test, there is a positif colleration between PLR and severity of stenosis $(p<0.048)$, with $R$ value $0.189(3.6 \%)$.

Conclusions: There was a poor correlation between PLR and degree of stenosis severity in CAD. A prospective study needed to assess PLR as predictor of mortality and morbidity in CAD.

Keyword : atherosclerosis, CAD, Gensini score, Pletelet to lymphocyte ratio

Cite This Article: Kasim, Z.I., Wibawa, S.Y., Rauf, D.E. 2019. Analisis hubungan Rasio Trombosit Limfosit (RTL) dengan derajat keparahan stenosis pada pasien Coronary Artery Disease (CAD). Intisari Sains Medis 10(2): 388-392. D0I: 10.15562/ism.v10i2.360

\section{ABSTRAK}

Latar Belakang: Aterosklerosis pada CAD ditandai dengan terbentuknya plak (ateroma) yang menempel pada lumen arteri. Trombosit berperan pada proses pembentukan dan perkembangan aterosklerosis. Perlengketan trombosit dengan sel endotel diikuti dengan pengeluaran granula trombosityang selanjutnya menyebabkan inflamasi endotel. Limfosit berperan dalam proses aterosklerosis dan aterotrombosis. Sel limfosit T adalah sel yang pertama kali masuk ke dalam ateroma dan banyak terkandung dalam plak yang tidak stabil. Derajat keparahan stenosis dapat dihitung dengan skor Gensini. Tujuan penelitian ini adalah untuk mengetahui hubungan antara rasio trombosit limfosit dengan derajat keparahan stenosis pada pasien CAD. Metode: Penilian ini menggunakan design retrospektif dengan mengambil data 110 pasien CAD yang dilakukan tindakan angiografi. RTL dihitung dari jumlah trombosit dibagi limfosit absolut, trombosit dan limfosit dihitung dengan alat hematologi. Hasil angiografi dihitung derajat keparahan stenosisnya berdasarkan skor Gensini, kemudian dibagi menjadi kelompok lesi ringan, sedang, berat.

Hasil: Total 110 pasien diteliti, didapatkan 80\% laki-laki dan 20\% wanita. Usia terbanyak yaitu 50-59 tahun (35.5\%). Dengan Uji Anova ditemukan perbedaan signifikan antara ketiga kelompok lesi ( $p<0.05$ ). Hasil uji Posthoc menunjukkan hasil bermakna adalah pada RTL antara kelompok lesi sedang dan berat. Dengan uji korelasi Spearman diperoleh korelasi positif antara RTL dengan derajat keparahan stenosis $(\mathrm{p}<0.048 ; \mathrm{R}=0.189)$.

Kesimpulan: Terdapat korelasi lemah antara RTL dengan derajat keparahan stenosis pada CAD. Diperlukan suatu studi prospektif untuk menilai RTL sebagai prediktor mortalitas dan morbiditas pada pasien CAD.

*Korespondensi:

Zahra Inayah Kasim; Program Pendidikan Dokter Spesialis IImu Patologi Klinik FK UNHAS / RSUP dr. Wahidin Sudirohusodo, Makassar, Indonesia,

inayahzara@yahoo.com

Diterima: $13-11-2018$

Disetujui: 17-04-2019

Diterbitkan: 01-08-2019
Kata Kunci : aterosklerosis, CAD, skor Gensini, Rasio Trombosit Limfosit

Cite Pasal Ini: Kasim, Z.I., Wibawa, S.Y., Rauf, D.E. 2019. Analisis hubungan Rasio Trombosit Limfosit (RTL) dengan derajat keparahan stenosis pada pasien Coronary Artery Disease (CAD). Intisari Sains Medis 10(2): 388-392. DOI: 10.15562/ism.v10i2.360

\section{PENDAHULUAN}

Coronary Artery Disease (CAD) termasuk dalam kelompok penyakit kardiovaskuler yang merupakan suatu masalah kesehatan dunia yang bersifat epidemik. CAD terdiri atas Angina stabil dan sindrom 
koroner akut. Menurut kelompok umur, CAD paling banyak terjadi pada kelompok umur 65-74 tahun. CAD menjadi penyakit kardiovaskuler yang paling banyak menyebabkan kematian yaitu sekitar 42.3 \%. Survei Sample Regristration System (SRS) pada 2014 di Indonesia menunjukkan CAD menjadi penyebab kematian tertinggi yakni sebesar $12.9 \%$. Penyakit kardiovaskular terutama penyakit jantung koroner pada tahun 2020 diprediksi akan tetap menjadi penyebab kematian utama di negara-negara berkembang, termasuk Indonesia. ${ }^{1,2}$

CAD disebabkan oleh proses aterotrombosis yaitu aterosklerosis dan trombosis. Ateroskleorosis ditandai dengan terbentuknya plak (ateroma) yang menempel pada lumen arteri. Plak ini terdiri atas lipid-filled macrophages (foam cells,) sel otot polos, dan jaringan pengikat. Faktor resiko untuk aterosklerosis adalah dislipidemia, diabetes, hipertensi, perokok, adanya riwayat keluarga, dan gaya hidup. ${ }^{3}$ Trombosit berperan pada proses pembentukan dan perkembangan aterosklerosis. Adhesi trombosit dengan sel endotel pada arteri terjadi sebelum lesi aterosklerosis terlihat. Sel endotel mensekresikan vWF (Von Willebrand Factor) dalam jumlah besar sebagai respon terhadap stimulus inflamasi. Von Willebrand Factor ini merekrut trombosit di area tersebut. Interaksi antara glikoprotein Ib dan vWF menyebabkan trombosit bergerak diatas endotel kemudian melekat. Perlengketan trombosit dengan sel endotel diikuti dengan pengeluaran granula-granula trombosit yang selanjutnya menyebabkan inflamasi endotel, sehingga trombosit memegang peranan penting dalam inisiasi dan perkembangan aterosklerosis. ${ }^{4,5}$

Limfosit berperan dalam proses aterosklerosis dan aterotrombosis. Sel limfosit $\mathrm{T}$ adalah sel yang pertama kali terekrut ke dalam ateroma dan banyak terkandung dalam plak yang tidak stabil atau plak yang mudah ruptur sehingga dapat menyebabkan trombosis, emboli dan manifestasi kardiovaskular yang bersifat akut. ${ }^{6}$

Hubungan antara jumlah leukosit dan peningkatan resiko kardiovaskulaer telah banyak diketahui. Jumlah neutrofil yang tinggi menggambarkan respon inflamasi, sedangkan jumlah limfosit yang rendah menggambarkan status kesehatan umum yang buruk dan stress psikologis. Jumlah limfosit dianggap sebagai penanda awal untuk stress psikologis dan kegagalan sistemik sekunder terhadap iskemia miokardium yang dimediasi oleh pelepasan kortisol. Sebaliknya, jumlah limfosit yang meningkat menunjukkan respon imun yang sesuai yang mengarah ke outcome yang lebih baik pada pasien angina tidak stabil. ${ }^{7}$

Tingkat keparahan CAD bisa dinilai secara objektif dengan pemeriksaan angiografi koroner. Salah satu cara menentukan tingkat keparahan CAD dengan menggunakan skor Gensini. Penggunaan skor Gensini ini berdasarkan evaluasi dari jumlah segmen arteri coronaria yang stenosis, berat stenosisnya dan lokasi dari segmen yang terjadi stenosis. ${ }^{8,9}$ Jumlah trombosit yang meningkat dihubungkan dengan outcome kejadian kardiovaskuler yang buruk. Demikian halnya dengan hitung limfosit yang rendah secara signifikan dan independen berhubungan dengan morbiditas dan mortalitas kardiovaskuler. Kombinasi kedua parameter ini saat ini menjadi suatu penanda inflamasi yang potensial dan sebagai prediktor untuk outcome berbagai penyakit kardiovaskular. ${ }^{8,9}$ Tujuan penelitian ini untuk membuktikan bahwa nilai rasio trombosit limfosit yang tinggi dapat dijadikan marker sederhana untuk mengetahui keparahan CAD dan prognosis yang buruk pada pasien CAD, khususnya di daerah Makassar.

\section{METODE PENELITIAN}

Penelitian ini merupakan penelitian retrospektif dengan mengambil data rekam medis pasien dewasa (>18 tahun) dengan diagnosa CAD di RSUP Dr. Wahidin Sudirohusodo Makassar periode Juli 2018 sampai September 2018. Diagnosa CAD ditegakkan oleh klinisi berdasarkan gejala klinis, angiografi dan pemeriksaan penunjang. Semua pasien dengan diagnosa CAD yang memiliki data yang lengkap berupa hasil pemeriksaan darah rutin dan angiografi diambil sebagai sampel. Jumlah trombosit dan jumlah limfosit diambil dari hasil pemeriksaan darah rutin yang diperiksa dengan menggunakan alat hematology analyzer Sysmex XN 1000.

Nilai normal untuk trombosit adalah 150.000 400.000, sedangkan jumlah limfosit normal berkisar 20-40 persen dari total leukosit. Pemeriksaan Angiografi koroner adalah pemeriksaan yang dilakukan untuk mengamati pembuluh darah jantung, berupa jenis, jumlah, derajat dan lokasi lesi arteri koroner. Hasil darah rutin dan angiografi yang diambil adalah hasil sebelum pasien mendapatkan tindakan Percutaneus Coronary Intervension. Berdasarkan data hasil angiografi maka selanjutnya dinilai derajat keparahan stenosis berdasarkan skor Gensini.

Analisa data dilakukan dengan menggunakan SPSS versi 22. Metode analisa statistik yang dilakukan adalah perhitungan statistik deskriptif, sebaran frekuensi dan uji statistik Anova dan Spearmen's Correlation. Hasil uji signifikan jika $\mathrm{p}<0.05$.

\section{HASIL}

Sejumlah 110 pasien dengan diagnosa CAD diambil sebagai sampel dengan rentang usia antara 
Tabel 1 Sebaran Karakteristik Sampel dengan CAD

\begin{tabular}{llcc}
\hline Variabel & Kategori & $\mathbf{n}$ & $\%$ \\
\hline Jenis Kelamin & Laki-Laki & 88 & 80.0 \\
Umur (tahun) & Perempuan & 22 & 20.0 \\
& $<40$ & 6 & 5.5 \\
& $40-49$ & 32 & 29.1 \\
& $50-59$ & 39 & 35.5 \\
& $60-69$ & 27 & 24.5 \\
& $>=70$ & 6 & 5.5 \\
\hline
\end{tabular}

Tabel 2 Rerata RTL menurut derajat keparahan stenosis

\begin{tabular}{lcccc}
\hline Derajat Keparahan & $\mathbf{n}$ & Mean & SD & P \\
\hline Lesi Ringan & 27 & 123.5 & 62.0 & $0.033^{\star}$ \\
Lesi Sedang & 25 & 105.0 & 32.2 & \\
Lesi Berat & 58 & 142.2 & 67.4 &
\end{tabular}

${ }^{*}$ Anova test: Nilai $P<0,05$ dikatakan bermakna secara statistik

Table 3 Korelasi RTL dengan Derajat Keparahan Stenosis

\begin{tabular}{llc}
\hline Variable & \multicolumn{2}{c}{ Derajat keparahan } \\
\hline RTL & $\mathrm{n}$ & 110 \\
& $\mathrm{r}$ & 0.189 \\
& $\mathrm{p}$ & $0.048^{\star}$
\end{tabular}

${ }^{*}$ Spearman's Correlation test; Nilai $P<0,05$ dikatakan bermakna secara statistik

20-86 tahun. Sebagian besar subyek yang diteliti adalah laki-laki (80.0\%) dengan usia yang paling banyak adalah 50-59 tahun (35.5\%).

Pada tabel 2 perbandingan rerata RTL menurut derajat keparahan menggunakan uji Anova menunjukkan adanya perbedaan signifikan $(\mathrm{p}<0.05)$. Pada analisis lanjutan (Posthoc test) didapatkan bahwa rerata RTL pada derajat berat (142.2) signifikan lebih tinggi dibandingkan derajat sedang (105.0) namun tidak berbeda signifikan dengan derajat ringan (123.5). Selanjutnya, rerata RTL derajat sedang tidak berbeda signifikan dengan derajat ringan (Gambar 1).

Hasil korelasi antara RTL dengan derajat keparahan stenosis menunjukkan adanya korelasi positif yang signifikan, dimana semakin tinggi RTL semakin tinggi derajat keparahan $(\mathrm{p}<0.05)$. Besarnya korelasi antara RTL dengan derajat keparahan stenosis adalah $(0.189)^{2}=0.036$ atau $3.6 \%$ (Gambar 2).

\section{PEMBAHASAN}

Penelitian ini menemukan bahwa dari 110 sampel penelitian yang didiagnosa sebagai CAD sejumlah $80 \%$ (88 orang) berjenis kelamin laki-laki sedangkan sisanya $20 \%$ (22 orang) adalah perempuan

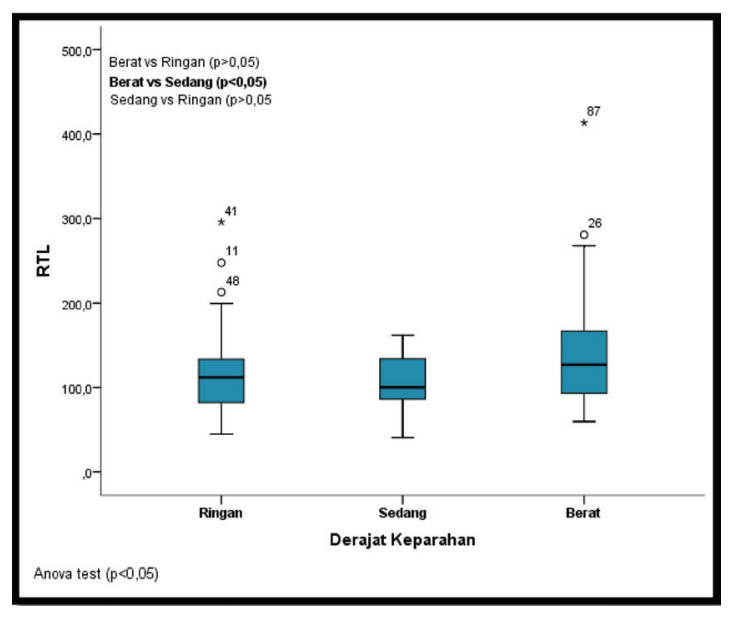

Gambar 1 Rerata RTL menurut Derajat Keparahan Stenosis

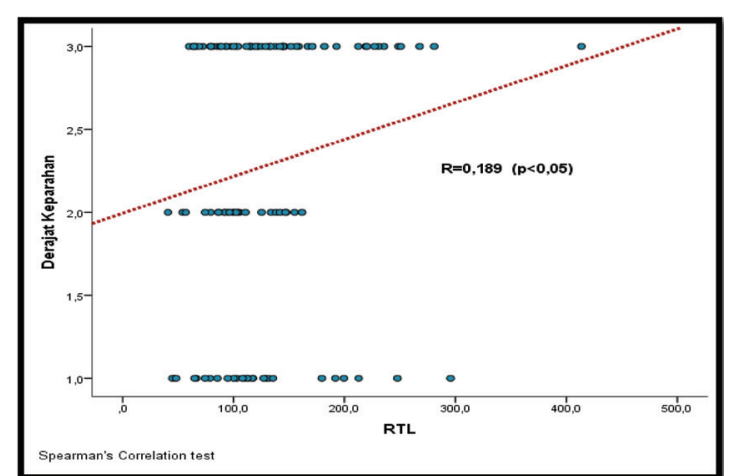

Gambar 2 Korelasi RTL dengan Derajat Keparahan Stenosis

dengan umur terbanyak yaitu 50-59 tahun. Hal ini sejalan dengan penelitian oleh Dong Zhou et al di Cina yang mendapatkan dari 113 sampel pasien CAD sekitar $68 \%$ adalah laki-laki dan sisanya perempuan dengan usia terbanyak adalah 52-72 tahun. $^{10}$

Untuk menilai derajat keparahan CAD yaitu dengan tindakan angiografi koroner yang menilai pembuluh darah jantung berupa jenis, jumlah, derajat dan lokasi lesi arteri koroner. Dari hasil angiografi koroner serta penghitungan skor Gensini akan didapatkan derajat keparahan CAD yakni lesi ringan (skor 1-6), lesi sedang (skor 7-13), dan lesi berat (skor $>13$ ).

Pada penelitian ini pengelompokan derajat keparahan stenosis berdasarkan rerata RTL didapatkan 27 pasien $(24.5 \%)$ lesi ringan dengan mean RTL 123.5, lesi sedang sebanyak 25 pasien (22.7\%) dengan mean RTL 105.0 dan 56 pasien (52\%) lesi berat dengan mean RTL 142.2. Dengan analisis statistik uji Anova didapatkan perbedaan yang signifikan dengan $\mathrm{p}<0.05(0.033)$.

Dari analisis data lanjutan (Posthoc test) didapatkan bahwa rerata RTL pada lesi berat (142.2) signifikan lebih tinggi dibandingkan lesi sedang 
(105.0) namun tidak berbeda signifikan dengan lesi ringan (123.5). Selanjutnya, rerata RTL derajat sedang tidak berbeda signifikan dengan derajat ringan. Rerata RTL antara lesi berat dan lesi sedang berbeda signifikan, yaitu 142.2 dan 105.0 hal ini sejalan dengan beberapa penelitian sebelumnya yang menyatakan nilai RTL yang meningkat berhubungan dengan derajat stenosis pada CAD.

Sedangkan temuan rerata RTL antara lesi ringan dan lesi berat tidak berbeda signifikan diduga oleh karena limfosit $\mathrm{T}$ sebagai pro atherogenic bersifat konstan pada semua tahapan lesi. Penelitian oleh De Boer et al. menyatakan bahwa pada manusia dan tikus yang imunokompeten, rekrutmen sel inflamasi termasuk limfosit $\mathrm{T}$ ke dalam tunika intima arteri merupakan gambaran yang konstan sepanjang semua tahap perkembangan dan perjalanan lesi. Sel limfosit T dapat diamati secara imunohistokimia pada tahap pre-lesi dan lesi awal seperti fatty streak yaitu bentuk CD25+, yang menandakan bahwa sifatnya aktif. ${ }^{11}$ Selain limfosit $\mathrm{T}$ banyak faktor lain yang mempengaruhi perjalanan lesi aterosklerotik antara lain peran cedera endotel, radang, lemak, sel-sel otot polos dan infeksi. Proses radang terjadi di setiap tahap aterosklerosis. Hal utama yang menginisiasi proses radang ini adalah cedera endotel. Proses radang pada bercak ateroma arteri coronaria dapat merupakan predisposisi terhadap terjadinya trombosis dan infark jantung. ${ }^{12}$

Jumlah trombosit dan aktivasi trombosit yang meningkat memiliki peranan penting dalam pembentukan trombus dan progresifitas aterosklerosis. Telah diketahui bahwa jumlah trombosit yang normal atau meningkat sebagai respon terhadap dinding arteri yang abnormal dapat mengakibatkan trombosis arterial. ${ }^{10}$ Pada penelitian ini jumlah trombosit pada 110 pasien CAD dalam batas normal atau sedikit meningkat.

Inisiasi dan progresifitas aterosklerosis pada dinding arteri dipengaruhi oleh banyak faktor. Inflamasi mempunyai peranan penting dalam tiap tahapan aterosklerosis sejak inisiasi sampai tahap progresi, hingga sampai tahap trombotik. Limfositopenia adalah temuan yang umum pada inflamasi kronik karena meningkatnya apoptosis limfosit. Produksi leukosit di sumsum tulang akan lebih meningkat dan menurunkan produksi limfosit karena respon terhadap stress. ${ }^{7}$

Untuk uji korelasi antara RTL dengan derajat keparahan stenosis pada penelitian ini menunjukkan korelasi yang positif, yaitu semakin tinggi nilai RTL maka derajat keparahan stenosis juga meningkat dengan nilai $\mathrm{p}=0.048(<0.05)$. Tetapi untuk besarnya korelasi sangat kecil yaitu $r=0.036$ yang menunjukkan suatu korelasi yang lemah. Hal ini menandakan bahwa RTL berhubungan dengan derajat keparahan stenosis tetapi multifaktorial juga turut mempengaruhi derajat keparahan stenosis. Pada penelitian ini pengambilan data jumlah trombosit dan limfosit tidak bersamaan dengan tindakan angiografi sehingga rasio trombosit limfosit yang dihitung bisa mengalami dinamika selama periode tersebut. Penelitian ini juga tidak dapat menilai adanya penyakit penyerta atau faktor-faktor resiko lain yang dapat mempengaruhi rasio trombosit limfosit maupun derajat keparahan stenosis.

\section{SIMPULAN}

Penelitian ini menunjukkan bahwa terdapat hubungan antara rasio trombosit limfosit dengan derajat keparahan stenosis pada pasien CAD tetapi dengan korelasi yang lemah. Kami menyarankan untuk melanjutkan dengan penelitian prospektif untuk menilai rasio trombosit limfosit sebagai prediktor mortalitas atau morbiditas pada pasien CAD dengan design yang lebih tepat.

\section{ETIKA PENELITIAN}

Persetujuan etika penelitian telah diterima oleh FK UNHAS / RS Stella Maris Makassar, Indonesia sebelum penelitian dijalankan.

\section{KONFLIK KEPENTINGAN}

Tidak terdapat konflik kepentingan dalam penulisan laporan hasil penelitian.

\section{PENDANAAN}

Studi ini sepenuhnya didanai oleh penulis sendiri tanpa keterlibatan pendanaan dari pihak sponsor, beasiswa, maupun sumber pendanaan lainnya.

\section{KONTRIBUSI PENULIS}

Seluruh penulis memiliki kontribusi yang sama dalam penulisan artikel baik saat persiapan proposal penelitian, pencarian sampel penelitian, analisis data, hingga laporan akhir penelitian.

\section{DAFTAR PUSTAKA}

1. Kemenkes RI. Penyakit Jantung Penyebab Kematian Tertinggi. 2017. Dapat diakses pada www.depkes.go.id.

2. Indonesia PDSK. Pedoman Tata Laksana Sindrom Koroner Akut. Jakarta; 2015.

3. Thanassoulis G, Ashar M. Atherosclerosis in Cardiovascular Disorders. MSD Manual Professional Edition. 2016; 1-18.

4. Ambrose J, Singh M. Pathophysiology of Coronary Artery Disease leading to Acute Coronary Syndromes. F1000Prime Rep. 2015;7:08.

5. Davi G, Patrono C. Platelet Avtivation and Atherothrombosis. N Engl J Med. 2007; 357: 2482-2494. 
6. Akboga MK, Canpolat U, Yayla C, Ozcan F, Ozeke O, Topaloglu S, Aras D.. Association of platelet to lymphocyte ratio with inflammation and severity of coronary atherosclerosis in patients with stable coronary artery disease. Angiology. 2016; 67(1):89-95

7. Oylumlu M, Yildız A, Oylumlu M, Yüksel M, Polat N, Bilik MZ, et al. Platelet to lymphocyte ratio is a predictor of in-hospital mortality patients with acute coronary syndrome. Anatol J Cardiol. 2015;15(4):277-83

8. Gensini GG. Coronary Arteriography. In : Heart Disease, Braunwald E. WB Saunders. 1980:352-3

9. Chen ZW, Chen YH, Qian JY, Ma JY, Ge JB. Validation of a Novel Clinical Prediction Score for Severe CAD before Elective Coronary Angiography. PLoS One. 2014; 9(4):e94493

10. Zhou D, Wang G, Fan Y, Wan Z, Liu X. Platelet to lymphocyte ratio is associated with the severity of CAD and clinical outcomes of PCI in Chinese Han population. Exp Ther Med. 2017; 13(2):731-738
11. de Boer OJ, Becker AE, van der Wal AC. T lymphocytes in atherogenesis-functional aspects and antigenic repertoire. Cardiovasc Res. 2003; 60(1):78-86.

12. Poppy LM. Perkembangan Konsep Patogenesis Aterosklerosis. Laboratorium PA FK Unsrat Manado. Jurnal Biomedik. 2009; (1)12-22.

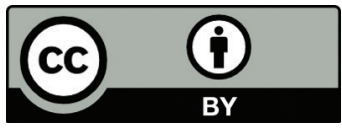

This work is licensed under a Creative Commons Attribution 